\title{
New Editorial Office Address
}

The BBS Editorial Office has moved to Southampton, United Kingdom.

Please address all BBS correspondence to:

Behavioral and Brain Sciences
Department of Psychology
University of Southampton
Southampton SO17 1BJ
United Kingdom

New Instructions for Authors and Commentators

(1) All Commentaries and Responses will, like Target Articles, have abstracts ( $\sim 60$ words). This is to ensure full coverage by abstracting services.

(2) In addition to the hard copies of all submissions, we will also require an electronic version, either by email or on disk. This is to prepare the way for electronic processing of all submissions. Disks should be in Word $^{\mathrm{TM}}$ or WordPerfect ${ }^{\mathrm{TM}}$ for Macintosh or IBM-compatible format.

Target articles should be sent to the new BBS address in Southampton listed above.

Commentaries and Responses should be sent to:

Behavioral and Brain Sciences

Cambridge University Press

Journals Department

40 West 20th Street

New York, NY 10011-4211

email: bbs@cup.org

\section{BBS Email Address}

bbs@ecs.soton.ac.uk

BBS Associates: Those of you who have not done so are asked to send us your email address so you may receive electronic Calls for Commentators. 


\section{BBS Associateship}

Qualified professionals in the biobehavioral sciences who have either (1) been nominated by a current BBS Associate, (2) refereed for BBS, or (3) had a commentary or article accepted for publication are eligible to become BBS Associates. Editors of learned journals and officers of learned societies in the biobehavioral sciences are invited to become BBS Associates ex officio. Detailed protocol cards indicating each Associate's specialization and interests are maintained by BBS to help in selecting commentators. Associates have a direct role in shaping BBS policy and are eligible to receive the journal at a special rate. Please write to the editor for further information. New BBS Associates, July 1993 to July 1994: [See BBS 3:4 (1980), 4:4 (1981), 5:4 (1982), 6:4 (1983), 7:4 (1984), 8:4 (1985), 9:4 (1986), 10:4 (1987), 11:4 (1988), $12: 4$ (1989), 13:4 (1990), 14:4 (1991), 15:4 (1992), 16:4 (1993), and 17:4 (1994) for full earlier lists of Associates.]

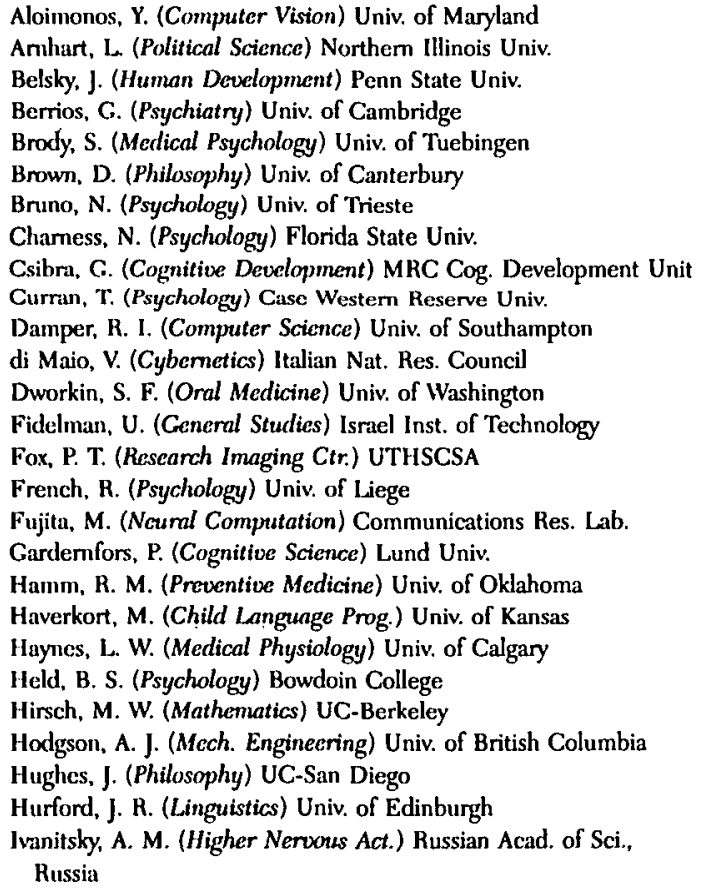

Kanekar, S. (Social Psychology) UC-San Diego

Kay, B. A. (Cognitive Science) Brown Univ. Kirby, S. (Linguistics) Univ. of Edinburgh Levy, Y. (Psychology) Hebrew Univ. Lidierth, M. (Physiology) UMDS Liska, J. (Behavioural Biology) Univ. of Colorado Lloyd-Jones, T. J. (Psychology) Univ. of Kent Lowenstein, P. R. (Physiology) Univ. of Wales Martin-Codero, J. (Psychology) Univ. of Ciudad Maryanski, A. (Sociology) UC-Riverside McCauley, C. (Psychology) Bryn Mawr College Miall, R. C. (Physiology) Univ. of Oxford Millar, M. G. (Psychology) Univ. of Nevada Milner, P. (Psychology) McGill Univ. Molnar, M. (Psychology) Hung. Acad. of Science Monk, R. (Philosophy) Univ, of Southampton Mosterin, J. (Philosophy of Science) Univ. of Barcelona Nayak, A. C. (Computer Science) Univ. of Sydney Newmeyer, F. (Linguistics) Univ. of Washington Nobuo, K. (Integrative Brain Science) Kyoto Univ. O'Brien, D. P. (Psychology) CUNY O'Nuallain, S. (Cognitive Science) Dublin City Univ. Paulin, M. G. (Zoology) Univ. of Otago Perrucnet, P. (Fac. des Sciences) Univ. of Bourgogne Plunkett, K. (Psychology) Univ. of Oxford Pollack, J. (Computer Science) Brandeis Univ. Rapp, P. (Physiology) Med. College of Pennsylvania Reisberg, D. (Psychology) Reed College

Repp, B. H. (Music Psychology) Haskins Lab. Rispoli, M. (Psychology) Northern Arizona Univ. Rodkin, P. C. (Human Development) Univ. of North Carolina Sanford, A. (Psychology) Univ. of Glasgow Schaller, M. (Psychology) Univ. of Montana Schyns, P. (Psychology) Univ. of Montréal Scott, S. H. (Physiology) Univ. of Montréal Slater, C. (Psychology) Alma College

Smith, T. (Philosophy of Science) Univ. of District Columbia Solso, R. (Cognitive Psychology) Univ. of Nevada Steele, J. (Archaeology) Univ. of Southampton Stevens, C. (Psychology) Univ. of Queensland Stewart, T. R. (Policy Research) SUNY Summers, C. (Psychology) Laurentian Univ. Tonnessen, F. E. (Ctr. Reading Res.) Stavanger Treffner, P. J. (Complex Systems) Florida Atlantic Univ. Tyrrell, T. (Marine Lab.) Plymouth Marine Lab. Vainikka, A. (Cognitive Science) Univ, of Pennsylvania Whitcombe, E. (Physiology) Univ. College London White, L. (Linguistics) McGill Univ. Wolfe, N. (Bioanthropology) Harvard Univ. Zohar, A. H. (Human Genetics) Hebrew Univ.

Please note that owing to the moving of the BBS Editorial Office from Princeton to Southampton and the reorganization and redistribution of BBS Editorial Office procedures between CUP/NY and BBS/UK, this year's Associate list is not yet complete. The rest of the 1995 Associates will appear in BBS 19(1) 1996. We apologize to new BBS Associates whose announcement has been delayed. 


\section{New Edition}

\section{Scientific Style and Format}

The CBE Manual for Authors, Editors, and

Publishers

Sixth Edition

\section{Edward J. Huth}

From reviews of the Sixth Edition:

"There is no other book like this for the scientific and technological community. It should be the major desk reference for anyone writing a scientific article or book. Students should be made aware of the manual early in their educational career so that old habits can be broken and correct procedures adhered to. Highly recommended....

-Booklist/Reference Books Bulletin

This detailed and authoritative manual is completely reorganized with coverage expanded to all sciences and with a new focus on general and scientific publication style and formats for science papers, journals, and books.

\section{Contents:}

PART 1: Scientific notation: A brief history/ PART 2: General style conventions/ Alphabets, symbols and signs/ Punctuation and related marks/Spelling and word formation/Prose style and word choice/ Names, terms of address, honors, and degrees/Capitalization/Type conventions, excerpts, quotations, and ellipses/Abbreviations/ Numbers, units, mathematical expressions, statistics/Times and dates/Addresses and geographic description/ PART 3: Special scientific conventions/ The electromagnetic spectrum/Subatomic particles, atoms, elements/Chemical formulas/ Chemical kinetics/Analytical methods/Drugs and pharmacokinetics/Cells, chromosomes, and genes/ Viruses/ Bacterial Plants and fungi/ Human and animal life/ Human history and society/ The Earth/ Astronomical objects and time systems/PART 4: Journals and books/Journal style and format/ Book style and format/Citations and references/Accessories to text: Tables, figures, and indexes/PART 5: Publishing progress/ Typography and manuscript markup, manual and electronic/ Proof correction
$1994782 \mathrm{pp}$.
47154-0
Hardback
$\$ 34.95$

Available in bookstores or from

\section{CAMBRIDGE UNIVERSITY PRESS}

40 West 20th Street,

New York, NY 10011-4211

Call toll-free 800-8 $\div 2-742.3$.

MasterCard/VISA accepted. Prices subject to change. 


\title{
Contents Volume 18:1 March 1995
}

\author{
Cordo, P. Controversies in Neuroscience II: Neural Transplantation: \\ Introduction
}

\author{
Neuwelt, E. A., Pagel, M. A., Geller, A. \& Muldoon, L. L. Gene \\ replacement therapy in the central nervous system: Viral vector-mediated \\ therapy of global neurodegenerative disease
}

\author{
Sinden, J. D., Hodges, H. \& Gray, J. A. Neural transplantation \\ and recovery of cognitive function
}

Stein, D. G. \& Glasier, M. M. Some practical and theoretical issues concerning fetal brain tissue grafts as therapy for brain dysfunctions

Open Peer Commentary

Anderson, B., Chatterjee, A. \& Graham, G. Neural transplants are grey matters

Baisden, R. H. Therapeutic uses for neural grafts: Progress slowed but not abandoned

Blount, J. B., Kondoh, T., Pundt, L. L., Conrad, J., Jansen, E. M. \& Low, W. C. Immunobiology of neural transplants and functional incorporation of grafted dopamine neurons

Bond, N. W. Repairing the brain: Trophic factor or transplant?

Cassel, J-C. \& Will, B. The structure, operation, and functionality of intracerebral grafts

Chiang, L., Flores, E. P., Wen, D. Y., Hall, W. A. \& Low, W. C. Gene therapy for neurodegenerative disorders and malignant brain tumors

Crutcher, K. A. The ethics of fetal tissue grafting should be considered along with the science

Davidson, B. L. The limitations of central nervous system directed gene transfer

Davis, H. P. \& Volpe, B. T. Building a rational

foundation for neural transplantation

Dunnett, S. B. Multiple potential mechanisms of graft action is not a new idea

Dunnett, S. B. \& Torres, E. M. Elegant studies of transplant-derived repair of cognitive performance

Felten, D. L. Transplantation, plasticity, and the aging host

Freed, W. J. \& Smith, T. D. Principles of brain tissue engineering

Haring, J. H. Therapeutic neural transplantation: Boon or boondoggle?

Li, Y. J. \& Low, W. C. Intraretrosplenial grafts of cholinergic neurons and spatial memory function

Lynch, M. P. Neural transplantation, cognitive aging, and speech

Moffett, S. B. Lessons on transplant survival from a successful model system

Mufson, E. J. \& Sobreviela, T. The NGF superfamily of neurotrophins: Potential treatment for Alzheimer's and Parkinson's disease

Nieto-Sampedro, M. CNS transplant utility may survive even their hasty clinical application

Privat, A. \& Giménez y Ribotta, M. The spinal cord as an alternative model for nerve tissue graft

48

49

51

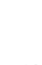

Ridley, R. M. Thinking about repairing thinking

Sanders, D. A. Multiple obstacles to gene therapy in the brain

Schallert, T. Models of neurological defects and defects in neurological models

Seigel, G. M. Gene replacement therapy in the CNS: A view from the retina

Silver, R. \& LeSauter, J. Studying restoration of brain function with fetal tissue grafts: Optimal models

Stanfield, B. B. Difficulties inherent in the restoration of dynamically reactive brain systems

Steece-Collier, K. Neural grafting in human disease versus animal models: Cautionary notes

Strata, P. \& Rossi, F. Pathway rewiring with neural transplantation

Svendsen, C. N. \& Dunnett, S. B. Gene therapy and neural grafting: Keeping the message switched on

Werth, R. Will brain tissue grafts become an important therapy to restore visual function in cerebrally blind patients?

Woodruff, M. L. Behavioral effects of neural grafts: Action still in search of a mechanism

\section{Authors' Responses}

Muldoon, L. L. \& Neuwelt, E. A. Local and global gene therapy in the central nervous system

Sinden, J. D., Hodges, H. \& Gray, J. A. Grafts and the art of mind's reconstruction

Stein, D. G. \& Glasier, M. M. Are fetal brain tissue grafts necessary for the treatment of brain damage? 


\section{Open Peer Commentary}

Baum, W. M. Patterns yes, agency no

Baumeister, R. F. Transcendence, guilt and self-control 122

Branch, M. N. When is a pattern a pattern? 123

Eisenberger, R. Does behaviorism explain self-control? 125

Fantino, E. The future is uncertain: Eat dessert first

Frank, R. H. Internal commitment and efficient habit formation

Green, L. \& Myerson, J. Choice between long- and short-term interests: Beyond self-control

Hineline, P. N. The extended psychological present

Hocutt, M. Self-control as habit

Hughes, J. \& Churchland, P. S. My behavior made me do it: The uncaused cause of teleological behaviorism

Kane, R. Patterns, acts, and self-control: Rachlin's theory 131

Kanekar, S. Conceptual problems in the act-versuspattern analysis of self-control

Killeen, P. R. The future of an illusion: Self and its control

Lacey, H. Teleological behaviorism and the intentional scheme

Lemm, K., Shoda, Y. \& Mischel, W. Can teleological behaviorism account for the effects of instructions on self-control without invoking cognition?
Logue, A. W. Form, function, and self-control

Mele, A. Conceptualizing self-control

Mosterin, J. Overcoming addiction through abstract patterns

Overskeid, G. Thinking is a difficult habit to break

Plaud, J. J. The behavior of self-control

Premack, D. \& Premack, A. J. Why self-control is both difficult and difficult to explicate

Schirillo, J. A. Self-control: Acts of free will

Shimoff, E. Distinguishing between acts and patterns

Silverstein, A. Teleological behaviorism and internal control of behavior

Smith, T. L. Alternatives to radical behaviorism

Summers, $C$. The role of discounting in global social issues

Tonneau, F. Further choices for molar theory

Waller, B. N. Pattern proliferation in teleological behaviorism

Wetherick, N. E. Commitment: Beyond Rachlin's control?

Zentall, T. R. The cost of an interrupted response pattern

\section{Author's Response}

Rachlin, H. Self-control observed
136

142

\section{Wilkins, W. K. \& Wakefield, J. Brain evolution and neurolinguistic preconditions}

\section{Open Peer Commentary}

Bickerton, D. Finding the true place of Homo habilis in language evolution

Bryant, D. J. Is preadaptation for language a necessary assumption?

Catania, A. C. Single words, multiple words, and the functions of language

Corballis, M. C. Lending a hand

Dingwall, W. O. Complex behaviors: Evolution and the brain 186

Donald, M. Neurolinguistic models and fossil reconstructions

Fitch, R. H. \& Tallal, P. A case for auditory temporal processing as an evolutionary precursor to speech processing and language function

Gibson, K. R. Solving the language origins puzzle: Collecting and assembling all pertinent pieces

Hauser, M. D. \& Wolfe, N. D. Human language: Are nonhuman precursors lacking?

Holloway, R. L. Evidence for POT expansion in early Homo: A pretty theory with ugly (or no) paleoneurological facts 191

Hurford, J. R. \& Kirby, S. Neural preconditions for proto-language

Jacobs, B. \& Horner, J. M. Language as a multimodal sensory enhancement system
Jerison, H. J. Issues in neo- and paleoneurology of language

Leiber, J. Coming of age in Olduvai and the Zaire rain forest

Lieberman, P. Manual versus speech motor control and the evolution of language

Liska, J. Semiogenesis as a continuous, not a discrete, phenomenon

Maryanski, A. The hominid tool-language connection: Some missing evolutionary links?

Mitchell, R. W. Apes and language: Human uniqueness again?

Newmeyer, F. J. Conceptual structure and syntax

Steele, J. Stone tools and conceptual structure

Walker, S. F. Bartering old stone tools: When did communicative ability and conceptual structure begin to interact?

Whitcombe, E. Palaeoneurology of language: Grounds for scepticism

\section{Authors' Response}

Wilkins, W. K. \& Wakefield, J. Issues and nonissues in the origins of language 


\title{
Contents Volume 18:2 June 1995
}

\author{
Block, N. On a confusion about a function of consciousness
}

Open Peer Commentary

Armstrong, D. M. Perception-consciousness and action-consciousness?

Atkinson, A. P. \& Davies, M. Consciousness without conflation

Baars, B. J. Evidence that phenomenal consciousness is the same as access consciousness

Bachmann, T. More empirical cases to break the accord of phenomenal and access-consciousness

Church, J. Fallacies or analyses?

Dennett, D. The path not taken

Dixon, N. F. Breakthrough on the consciousness front or much ado about nothing?

Farah, M. J. Is consciousness of perception really separable from perception?

Graham, G. Guilty consciousness

Harman, G. Phenomenal fallacies and conflations

Humphrey, N. Blocking out the distinction between sensation and perception: Superblindsight and the case of Helen

Katz, L. D. On distinguishing phenomenal consciousness from the representational

functions of mind

Kitcher, P. Triangulating phenomenal consciousness

Kobes, B. W. Access and what it is like

Levine, J. Phenomenal access: A moving target

Lloyd, D. Access denied
247

248

249

249
Lycan, W. G. We've only just begun

Morton, A. Phenomenal and attentional consciousness may be inextricable

Natsoulas, T. How access-consciousness might be a kind of consciousness

Navon, D. A-consciousness: The local newspaper of the mind?

Revonsuo, A. Conscious and nonconscious control of action

Rey, G. Block's philosophical anosognosia

Shepard, R. N. What is an agent that it experiences $\mathrm{P}$-consciousness? And what is $\mathrm{P}$-consciousness that it moves an agent?

Tye, M. Blindsight, orgasm, and representational overlap

Van Brakel, J. Consciousness is not a natural kind

Warren, R. M. Should we continue to study consciousness?

Zalla, T. \& Palma, A. P. Feeling of knowing and phenomenal consciousness

EDITORIAL COMMENTARY

\section{Author's Response}

Block, N. How many concepts of consciousness?

\section{Davey, G. C. L. Preparedness and phobias: Specific evolved associations or} a generalized expectancy bias?

\section{Open Peer Commentary}

Delprato, D. J. Heredity x environment or developmental interactions?

Edelmann, R. J. Innateness versus expectation in human fears: Causal versus maintaining factors?

Fantino, E. \& Goldshmidt, J. Rüle-governed and contingency-governed fears

Figueredo, A. J. A stochastic optimality theory of preparedness and plasticity

Hamm, A. Biologically primed acquisition of aversions and association of expected stimulus pairs: Two different forms of learning

Klein, D. F. Counterevidence from psychopharmacology, psychopathology, and psychobiology

Lovibund, P. F., Siddle, D. A. T. \& Bond, N. W. Why are phobias irrational?

McNally, R. J. Preparedness, phobias, and the Panglossian paradigm

Mealey, L. Enhanced processing of threatening stimuli: The case of face recognition

Menzies, R. G. The uneven distribution of fears and phobias: A nonassociative account

Miller, D. B. Nonlinear experiential influences on the development of fear reactions
Mineka, S. \& Cook, M. Expectancy bias as sole or partial account of selective associations?

Neese, R. M. \& Abelson, J. L. Natural selection and fear regulation mechanisms

Ohman, A. Eggs in more than one basket: Mediating mechanisms between evolution and phobias

Plaud, J. J. The generalized expectancy bias: An explanatory enigma

Schell, A. M. \& Dawson, M. E. Responses conditioned to fear-relevant stimuli survive extinction of the expectancy of the UCS

Sokolov, E. N. Phobias and anxiety in the framework of the defense reflex

Tomarken, A. J. What is the critical evidence favoring expectancy bias theory, and where is it?

Vaitl, D. Associative learning: Stimulus arrangement and response consistency

\section{Author's Response}

Davey, G. C. L. Expectancy bias and phobias: Accounting for the uneven distribution of fears and the characteristics of clinical phobias 


\section{Open Peer Commentary}

Burghardt, G. M. Brain imaging, ethology, and the nonhuman mind

Cotterill, R. M. J. Mindwatching

Dalenoort, G. J. Is attention an appropriate concept for explaining brain processes?

Donald, M. Tough times for dualists

Fidelman, U. The three attentional networks and the two hemispheric mechanisms

Fox, P. T. Broca's area: Motor encoding in somatic space

Freides, D. A major advance in neuropsychology

Frith, C. D. \& Dolan, R. J. Brain imaging the psychoses

Goertzel, B. Images in search of a theory

Goldberg, G. \& Mayer, N. H. The neurodynamics of heavy PETing, at/intention, learning, functional recovery, and rehabilitation

Grafman, J., Partiot, A. \& Hollnagel, C. Fables of the prefrontal cortex

Halgren, E. PET may image the gates of awareness, not its center

Hari, R. Tracking brain functions in space and time

Horwitz, B. Regions, networks: Interpreting functional neuroimaging data

Ingber, L. Multiple scales of brain-mind interactions
Jacobs, A. M. \& Carr, T. H. Mind mappers and cognitive modelers: Toward cross-fertilization

Jonides, J. \& Reuter-Lorenz, P. Redefining cognitive psychology

Kapur, N. Looking for images of memory

Kristeva-Feige, R. \& Feige, B. Is the human brain only responsive?

O'Mara, S. M. When is it sensible to use PET to study brain function?

Paller, K. A. If a picture is worth a thousand words, how many pictures is a word worth?

Perrone, A. L. \& Basti, G. Neural images and neural coding

Poeppel, D. \& Johnson, S. Neuroimaging studies of language should connect with (psycho)linguistic theories

Robinson, D. L. The meaning of baselines

Schmitt, G. J. E. Bright red spots or-the meaning of the meaning

Solso, R. L. Images of mind: A window to the brain

Tsotsos, J. K. Computation, PET images, and attention

\section{Authors' Response}

Posner, M. I. \& Raichle, M. E. Interaction of method and theory in cognitive neuroscience
362

363

364

365

366

367

368

369

370

370

371

372

\section{Continuing Commentary}

On Dunbar, R. I. M. (1993) Coevolution of neocortical size, group size and language in humans. BBS 16:681-735.

Bradshaw, J. Another far more ancient tongue

Jaffe, K. \& Chacon, G. Nonlinear trends in the evolution of the complexity of nervous systems, group size, and communication systems: A general feature in biology

Solso, R. L. The origin of language: More words needed.
Thompson, N. S. Does language arise from a calculus of dominance?

Author's Response

Dunbar, R. I. M. Neocortical size and language

On Gopnik, A. (1993) How we know our minds: The illusion of first-person knowledge of intentionality. BBS 16:1-14; Goldman, Alvin I. (1993) The psychology of folk psychology. BBS 16:15-28.

Bogdan, R. J. The epistemological illusion

Greve, W. \& Buchner, A. Speaking of beliefs: Reporting or constituting mental entities?

Pust, J. Two kinds of representational functionalism: Defusing the combinational explosion

Van Brakel, J. Interpreting self-ascriptions

\section{Authors' Responses}

Goldman, A. I. Epistemology, two types of functionalism, and first-person authority

Gopnik, A. How to understand beliefs 


\title{
Contents Volume 18:3 September 1995
}

\author{
Polans, A., Kaplan, M., Palczewski, K., Cordo, P., \& Harnad, S.
}

Controversies in neuroscience III: Signal transduction in the retina

Hargrave, P. A. Future directions for rhodopsin structure and function studies

Bownds, M. D. \& Arshavsky, V. Y. What are the mechanisms of photoreceptor adaptation?

Hurley, J. B. Recoverin and $\mathrm{Ca}^{2+}$ in vertebrate phototransduction

Xia, Z., Choi, E.-J., Storm, D. R. \& Blazynski, C. Do the calmodulinstimulated adenylyl cyclases play a role in neuroplasticity?

Molday, R. S. \& Hsu, Y.-T. The cGMP-gated channel of photoreceptor cells: Its structural properties and role in phototransduction

Daiger, S. P., Sullivan, L. S. \& Rodriguez, J. A. Correlation of phenotype with genotype in inherited retinal degeneration

\section{Open Peer Commentary}

Abrams, T. W. Calcium/calmodulin-sensitive adenylyl cyclase as an example of a molecular associative integrator

Albert, A. D. \& Yeagle, P. L. The determination of rhodopsin structure may require alternative approaches

Barnstable, C. J. Mechanisms of photoreceptor degenerations

Bergen, A. A. B. Genetic and clinical heterogeneity in tapetal retinal dystrophies

Brown, R. L. \& Karpen, J. W. Molecular insights gained from covalently tethering cGMP to the ligand-binding sites of retinal rod cGMP-gated channels

Crouch, R. K. \& Corson, D. W. The structure of rhodopsin and mechanisms of visual adaptation

Dratz, E. A. The key to rhodopsin function lies in the structure of its interface with transducin

Garavito, R. M. The atomic structure of visual rhodopsin: How and when?

Gray-Keller, M. P. \& Detwiler, P. B. Does calmodulin play a functional role in phototransduction?

Haynes, L. W. Structure and physiology of photoreceptor cGMP-gated cation channels

Heideman, W. Long term potentiation and CaMsensitive adenylyl cyclase: Long-term prospects

Hurwitz, R. L., Srivastava, D., \& Hurwitz, M. Y. Channel structure and divalent cation regulation of phototransduction
Kaplan, M. W. Linking genotypes with phenotypes in human retinal degenerations: Implications for future research and treatment

Kawamura, S. Unsolved issues in S-modulin/recoverin study
469
Koch, K.-W. Crucial steps in photoreceptor adaptation: Regulation of phosphodiesterase and guanylate cyclase activities an $\mathrm{Ca}^{2+}$-buffering

Matthews, H. R. \& Fain, G. L. Reduced cytoplasmic calcium concentration may be both necessary and sufficient for photoreceptor light adaptation

McGinnis, J. F. Gene therapy, regulatory mechanisms, and protein function in vision

Oprian, D. D. Structure of the cGMP-gated channel

Polans, A. S. \& Adamus, G. Recoverin is the tumor antigen in cancer-associated retinopathy

Rasenick, M. M. Adenylyl cyclase, G proteins, and synaptic plasticity

Roberson, E. D. \& Sweatt, J. D. Regulation of adenylyl cyclase in LTP

Sagoo, M. S. \& Lagnado, L. Modulation of the cGMP-gated channel by calcium

Sanada, K. \& Fukada, Y. Unique lipids and unique properties of retinal proteins

Schnetkamp, P. P. M. Na-Ca $+\mathrm{K}$ exchanger and $\mathrm{Ca}^{2+}$ homeostasis in retinal rod outer segments: Inactivation of the $\mathrm{Ca}^{2+}$ efflux mode and possible involvement of intracellular $\mathrm{Ca}^{2+}$ stores in $\mathrm{Ca}^{2+}$ homeostasis 
Smith, S. O. Nuclear magnetic resonance studies on the structure and function of rhodopsin

Takamatsu, K. A novel protein family of neuronal modulators

Tamai, M. Glutamate accumulation in the photoreceptor-presumed final common path of photoreceptor cell death

Wahlsten, D. The genetic kaleidoscope of vision

Wensel, T. G. \& Angleson, J. K. More answers about cGMP-gated channels pose more questions

Willardson, B. M., Yoshida, T., \& Bitensky, M. W. Cyclic nucleotides as regulators of light-adaptation in photoreceptors

Yamazaki, A. Is the lifetime of light-stimulated cGMP phosphodiesterase regulated by recoverin through its regulation of rhodopsin phosphorylation?

Authors' Responses

488

490

490
Hargrave, P. A. Future directions for rhodopsin structure and function studies

Bownds, M. D. \& Arshavsky, V. Y. How many light adaptation mechanisms are there?

Hurley, J. B. Recoverin, a calcium-binding protein in photoreceptors

Xia, Z. \& Storm, D. R. Evidence that the type I adenylyl cyclase may be important for neuroplasticity: Mutant mice deficient in the gene for type I adenylyl cyclase show altered behavior and LTP

Molday, R. S. \& Hsu, Y.-T. Further insight into the structural and regulatory properties of the cGMPgated channel

Daiger, S. P., Sullivan, L. S. \& Rodriguez, J. A. Genetic and functional complexity of inherited retinal degeneration

\section{Mealey, L. The sociobiology of sociopathy: An integrated evolutionary model}

\section{Open Peer Commentary}

Archer, J. Testing Mealey's model: The need to demonstrate an ESS and to establish the role of testosterone

Bailey, K. G. The sociopath: Cheater or warrior hawk?

Baldwin, J. D. Continua outperform dichotomies

Barratt, E. S. \& Gardner, R., Jr. Sociopathy, evolution, and the brain

Barresi, J. You can cheat people, but not nature!

Belsky, J. Secondary sociopathy and opportunistic reproductive strategy

Bergeman, C. S. \& Seroczynski, A. D. Group differences $\neq$ individual differences

Blair, R. J. R. \& Morton, J. Putting cognition into sociopathy

Campbell, A. Sociopathy or hyper-masculinity?

Carmichael, H. L. Cheaters never prosper, sometimes

Colman, A. M. Prisoner's Dilemma, Chicken, and mixed-strategy evolutionary equilibria

Crusio, W. E. The sociopathy of sociobiology

Drake, R. A. A neuropsychology of deception and selfdeception

Eisenberg, $\mathbf{N}$. The role of emotion in sociopathy: Contradictions and unanswered questions

Ellis, L. Extending arousal theory and reflecting on biosocial approaches to social science

Erickson, C. J. Sociopathy and sociobiology: Biological units and behavioral units

Eysenck, H. J. Psychopathology: Type or trait?

Figueredo, A. J. The epigenesis of sociopathy

Futterman, A. \& Allen, G. E. "Just So" stories and sociopathy

Gudjonsson, G. H. The primary/secondary distinction of psychopathy: A clinical perspective

Holcomb, H. R., III Implications of an evolutionary biopsychosocial model

Hoyenga, $\mathbf{K}$. Genes, hormones, and gender in sociopathy

Kenrick, D. T. \& Brown, S. Al Capone, discrete morphs, and complex systems

Kosson, D. S. \& Newman, J. P. An evaluation of Mealey's hypotheses based on psychopathy checklist: Identified groups
Lykken, D. T. Fatherless rearing leads to sociopathy Machalek, R. Sociobiology, sociopathy, and social policy

Maxson, S. C. Genetic issues in "the sociobiology of sociopathy"

McFall, R. M., Townsend, J. T. \& Viken, R. J.

Diathesis-stress model or "Just So" story?

Moore, C. \& Rose, M. R. Adaptive and nonadaptive explanations of sociopathy

Neufeld, R. W. J. Touchstones of abnormal personality theory

Panksepp, J., Knutson, B. \& Bird, L. On the brain and personality substrates of psychopathy

Plomin, R. "Genetics" and DNA polymorphisms

Plutchik, R. Emotions and sociopathy

Quinsey, V. L. \& Lalumière, M. L. Psychopathy is a nonarbitrary class

Raine, A. Psychopathy and violence: Arousal, temperament, birth complications, maternal rejection, and prefrontal dysfunction

Rowe, D. C. Evolution, mating effort, and crime

Segal, N. L. Pathways to sociopathy: Twin analyses offer direction

Snyder; J. Is sociopathy a type or not? Will the "real" sociopathy please stand up?

Van IJzendoorn, M. H. The role of attachment in the development and prevention of sociopathy

Wilson, D. S. Sociopathy within and between small groups

Wolf, Y. Moral judgments by alleged sociopaths as a means for coping with problems of definition and identification in Mealey's model

Zuckerman, M. Is the distinction between primary and secondary sociopaths a matter of degree, secondary traits, or nature vs. nurture?

563

564

565

565

566

567

568

570

570

571

571

573

\section{Author's Response}

Mealey, L. Primary sociopathy (psychopathy) is a type, secondary is not 


\section{Contents Volume 18:4 December 1995}

Amit, D. J. The Hebbian paradigm reintegrated: Local reverberations as internal representations

Open Peer Commentary

Ahissar, E. Are single-cell data sufficient for testing neural network models?

Bienenstock, E. \& Geman, S. Where the adventure is

Chown, E. Reverberation reconsidered: On the path to cognitive theory

Dalenoort, G. J. \& de Vries, P. H. What's in a cell assembly?

Edelman, S. How representation works is more important than what representations are

Freeman, W. J. The Hebbian paradigm reintegrated: Local reverberations as internal representations

Fuster, J. M. Not the module does memory make-but the network

Hirsch, M. W. Mathematics of Hebbian attractors

Hoffman, R. E. Additional tests of Amit's attractor neural networks

Hucka, M., Weaver, M. \& Kaplan, S. Hebb’s accomplishments misunderstood

Klimesch, w. The functional meaning of reverberations for sensoric and contextual encoding

Krakauer, D. C. \& Houston, A. I. An evolutionary perspective on Hebb's reverberatory representations

Lansner, A. \& Fransén, E. Distributed cell assemblies and detailed cell models

Milner, P. M. Attractors-Don't get sucked in

Morita, M. Another ANN model for the Miyashita experiments

Petitot, J. The problems of cognitive dynamical models

Pulvermüller, F. \& Preissl, H. Local or transcortical assemblies? Some evidence from cognitive neuroscience

631 Raijmakers, M. E. J. \& Molenaar, P. C. M. How to decide whether a neural representation is a cognitive concept?

Rauschecker, J. P. Reverberations of Hebbian thinking van der Velde, F. Association and computation with cell assemblies

Wright, J. J. How do local reverberations achieve global integration?

Author's Response

Amit, D. J. Empirical and theorectical active memory: The proper context

Gray, J. A. The contents of consciousness: A neuropsychological conjecture

676

677

Crider, A. Segmentalized consciousness in schizophreni

Dennett, D. C. Overworking the hippocampus

Dennis, S. \& Humphreys, M. Possible roles for a predictor plus comparator mechanism in human episodic recognition memory and imitative learning

Diaz, J.-L. Hunting for consciousness in the brain: What is (the name of) the game?

Eichenbaum, H. \& Cohen, N. J. Consciousness, memory, and the hippocampal system: What kind of connections can we make?

Ellard, C. G. Context and consciousness

Foss, J. On seeking the mythical fountain of consciousness

Frith, C. Consciousness is for other people

Hemsley, D. R. Psychopathology and the discontinuity of conscious experience

Hurley, S. L. Perspective, reflection, transparent explanation, and other minds

Ingvaldsen, R. \& Whiting, H. T. A. Mind-your head!

Ivanitsky, A. M. Information synthesis in cortical areas as an important link in brain mechanisms of mind

Kinsbourne, M. Septohippocampal comparator: Consciousness generator or attention feedback loop?

Lloyd-Jones, T. J., Donnelly, N. \& Weekes, B. Correlating mind and body

Lubow, R. E. Human consciousness: One of a kind

680

681

682
Merskey, H. Comparators, functions, and experiences

Nelson, T. D. The control of consciousness via a neuropsychological feedback loop

Newman, J. Reticular-thalamic activation of the cortex generates conscious contents

Rachlin, H. The elusive quale

Reeke, G. N., Jr. Unitary consciousness requires distributed comparators and global mappings

Revonsuo, A. Prospects for a cognitive neuroscience of consciousness

Schmajuk, N. A. \& Axelrad, E. Communication and consciousness: A neural network conjecture

Shames, V. A. \& Hubbard, T. L. Consciousness beyond the comparator

Smith, J. D. The homunculus at home

Stephens, G. L. \& Graham, G. Ultimate differences

Swerdlow, N. R. Don't leave the "un" off "consciousness"

Toates, F. On giving a more active and selective role to consciousness

Umiltà, C. \& Zorzi, M. Consciousness does not seem to be linked to a single neural mechanism

Velmans, M. The limits of neurophysiological models of consciousness

\section{Author's Response}

Gray, J. A. Consciousness and its (dis)contents

Feldman, A. G. \& Levin, M. F. The origin and use of positional frames of reference in motor control

\section{Open Peer Commentary}

Alexander, R. McN. Tendon elasticity and positional control

Alexandrov, A., Frolov, A. \& Massion, J. Is the multijoint pointing movement model applicable to equilibrium control during upper trunk movements?
Bonnard, M. \& Pailhous, J. A few reasons why psychologists can adhere to Feldman and Levin's model

Corcos, D. M. \& Pfann, K. Conservative or nonconservative control schemes 


\section{Continuing Commentary}

On Lockhead, G. R. (1992) Psychophysical scaling: Judgments of attributes or objects? BBS 15:543-601.

Massaro, D. W. Processing attributes and judging objects 601

Müller, F. Arguments in favour of a psycho-psychophysics 602

Poulton, E. C. Bias by stimuli presented before the start of an investigation

Reeves, A. Psychophysical scaling: A conditional 604 defense of $R=f(I)$
Ross, H. E. Weight and mass as psychophysical attributes

Author's Response

Lockhead, G. R. Psychophysical scaling methods reveal and measure context effects

On Searle, J. R. (1990) Consciousness, explanatory inversion, and cognitive science. BBS 13:585-642.

Kurthen, M. \& Linke, D. B. The ontology of aspectual shape

Nelkin, N. Searle's argument that intentional states are conscious states
Schröder, J. Token-identity, consciousness, and the connection principle. 
Dean, J. The lambda model is only one piece in the motor control puzzle

Desmurget, M., Rosetti, Y. \& Prablanc, C. Natural unconstrained movements obey rules different from constrained elementary movements

Fidelman, U. The lambda model and a hemispheric motor model of intentional hand movements

Fikes, T. G. \& Townsend, J. T. Moving models of motion forward: Explication and a new concept

Flanagan, J. R., Tresilian, J. R. \& Wing, A. M. Grip force adjustments during rapid hand movements suggest that detailed movement kinematics are predicted

Gielen, C. C. A. M. \& van Bolhuis, B. Reciprocal and coactivation commands are not sufficient to describe muscle activation patterns

Giszter, S. The case of the missing CVs: Multi-joint primitives

Goodman, S. R. Inverse kinematic problem: Solutions by pseudoinversion, inversion and no-inversion

Gottlieb, G. L. Shifting frames of reference but the same old point of view

Haggard, P., Miall, C. \& Stein, J. Twisted pairs: Does the motor system really care about joint configurations?

Hamm, T. M. \& Han, Z.-S. Is $\lambda$ an appropriate control variable for locomotion?

Hatsopoulos, N. G. \& Warren, W. H., Jr. Do control variables exist?

Hodgson, A. The unobservability of central commands: Why testing hypotheses is so difficult

Ingvaldsen, R. \& Whiting, H. T. A. Frameworks on shifting sands

Kay, B. A. Frames of reference interact and are taskdependent

Latash, M. L. Equilibrium-point control? Yes! Deterministic mechanisms of control? No!

Lestienne, F., Ghafouri, M. \& Thullier, F. What does body configuration in microgravity tell us about the contribution of intra- and extrapersonal frames of reference for motor control?
Loeb, G. E. What can we expect from models of motor control?

McDonald, P. V. Can the $\lambda$ model benefit from understanding human adaptation in weightlessness (and vice versa)?

Morasso, P. \& Sanguineti, V. Kinematic invariances and body schema

Ostry, D. J., Laboissière, R. \& Gribble, P. L. Command invariants and the frame of reference for human movement

Nichols, T. N. Interneurons as backseat drivers and the elusive control variable

Pagano, C. C. \& Bingham, G. P. Spatial frames for motor control would be commensurate with spatial frames for vision and proprioception, but what about control of energy flows?

Partridge, L. D. Let us accept a "controlled trade-off" model of motor control

Patla, A. E. The $\lambda$ model: Can it walk?

Pribram, K. H. Position is everything?

Scott, S. H. Can the $\lambda$ model be used to interpret the activity of single neurons?

Smeets, J. B. J. Two joints are more than twice one joint

Sternad, D. \& Turvey, M. T. Control parameters, equilibria, and coordination dynamics

Thelen, E. Origins of origins of motor control

van Emmerik, R. E. A. \& Wagenaar, R. C. Equifinality and phase-resetting: The role of control parameter manipulations

Windhorst, $U$. Levers to generate movement

Winters, J. M. How far should we extend the equilibrium point (lambda) hypothesis?

Wright, C. E. \& States, R. A. Biological variability and control of movements via $\delta \lambda$

\section{Authors' Response}

Levin, M. F. \& Feldman, A. G. The $\lambda$ model for motor control: More than meets the eye

\section{Continuing Commentary}

On Dennett, D. C. \& Kinsbourne, M. (1992) Time and the observer: The where and when of consciousness in the brain. BBS 15:183-247.

Glicksohn, J. "Multiple Drafts" of subjective experience viewed within a microgenetic framework for cognition and consciousness

Salter, D. Consciousness and timing
Authors' Response

Dennett, D. C. \& Kinsbourne, M. Multiple Drafts: An eternal golden braid? 


\section{Cambridge - Bringing You the Psychologist's Best Friend}

\section{The Psychologist's Companion}

A Guide to Scientific Writing for Students and Researchers Third Edition

\section{Robert J. Sternberg}

".../students/ will find this book belpful becanse it contains good advice...[it] can be read with profit by those in fields otber than psychology where research is reported in the same format or in a similar one...linely, informative, and concise."

-Contemporary Psychology

"An extremely useful book for undergraduates that provides the basics for uriting psyclsology papers."

-Choice

Sternberg reviews rules for effective prose in a variety of formats, debunks common misconceptions about writing, highlights commonly misused words, gives instruction on the preparation of tables, figures, and bibliographies, and explains the American Psychological Association guidelines for psychology papers. He has also updated the volume's references.

\section{Contents:}

- Eight common misconceptions about psychology papers - Steps in writing the library research paper

- Steps in writing the experimental research paper $\bullet$ Rules for writing the psychology paper $\bullet$ Commonly misused words $\bullet$ American Psychological Association guidelines for psychology papers $\bullet$ Guidelines for data presentation $\bullet$ References for the psychology paper $\bullet$ Standards for evaluating the psychology paper - Submitting a paper to a journal $\bullet$ How to win acceptances from psychology journals: Twenty-one tips for better writing $\bullet$ Writing a grant proposal $\bullet$ Finding a publisher $\bullet$ Writing a lecture

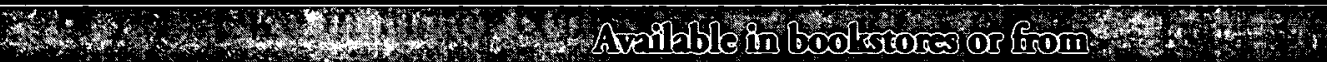

\section{CAMBRIDGE} UNIVERSTTYRSES
40 West 20th Street, New York, NY 10011--4211 Call toll-free 800-8-2.-42.3.

MasterCard/ $1 S A$ accepted. Prices subjece to change 


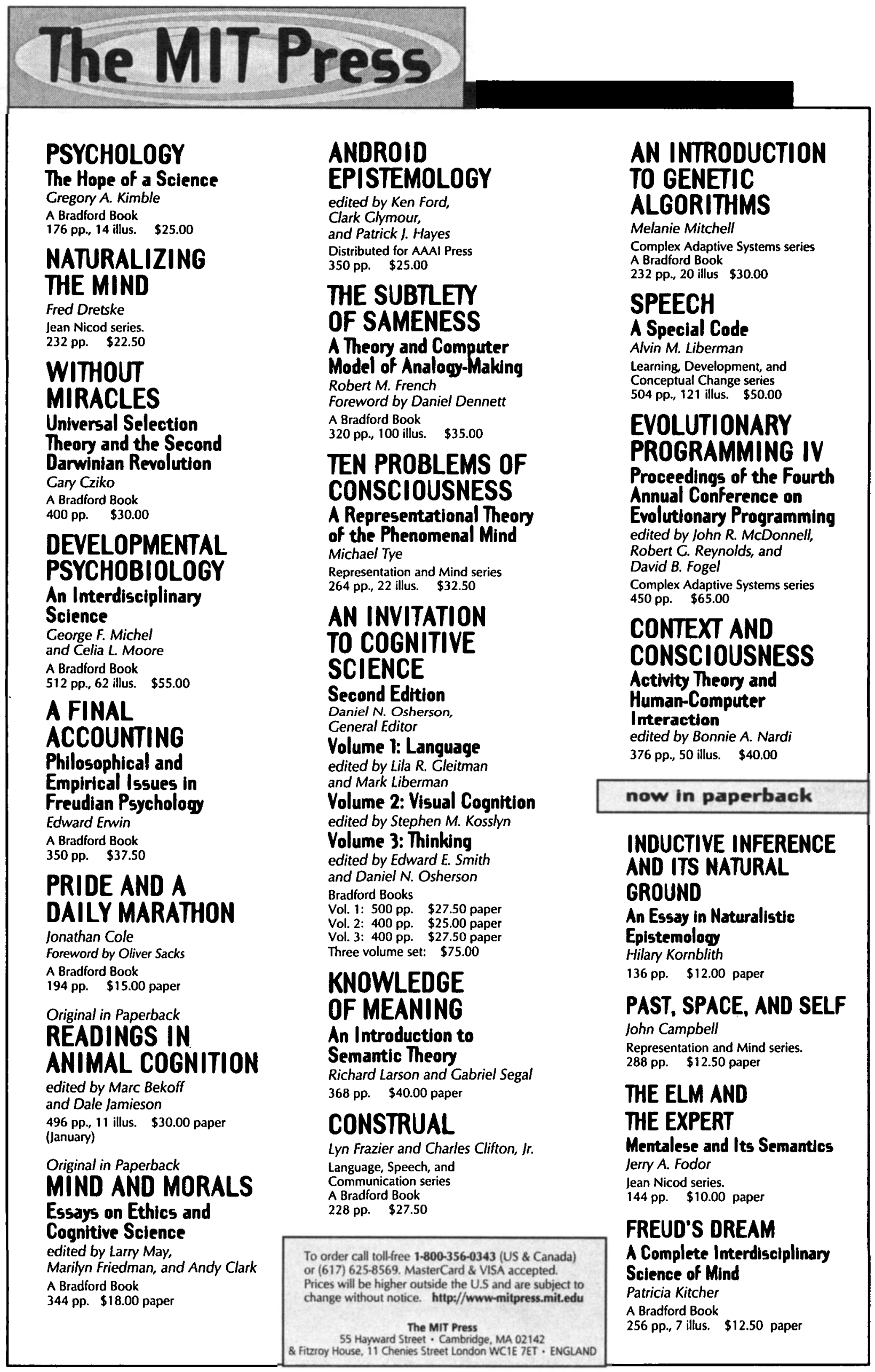




\section{New in 1995 from Cambridge University Press!}

Journal of the International Neuropsychological Society

Editor-in Chief: IGOR GRANT, M.D., University of California, San Diego

JINS aims to further scientific and research activities in neuropsychology and enhance communication among its cognate member disciplines. The journal publishes scholarly, peer-reviewed articles and will include original research, timely review articles and transactions of the INS annual meetings. Contributions reflect the interest of all areas of neuropsychology, including but not limited to: development of cognitive processes, brain-behavior relationships, adult neuropsychology, child neuropsychology, developmental neuropsychology, disorders of speech and language, and relared topics such as behavioral neurology, neuropsychiatry, neuroimaging, and electrophysiology. The journal also includes articles employing neuropsychological methods which use an experimental, more applied or clinical approach.

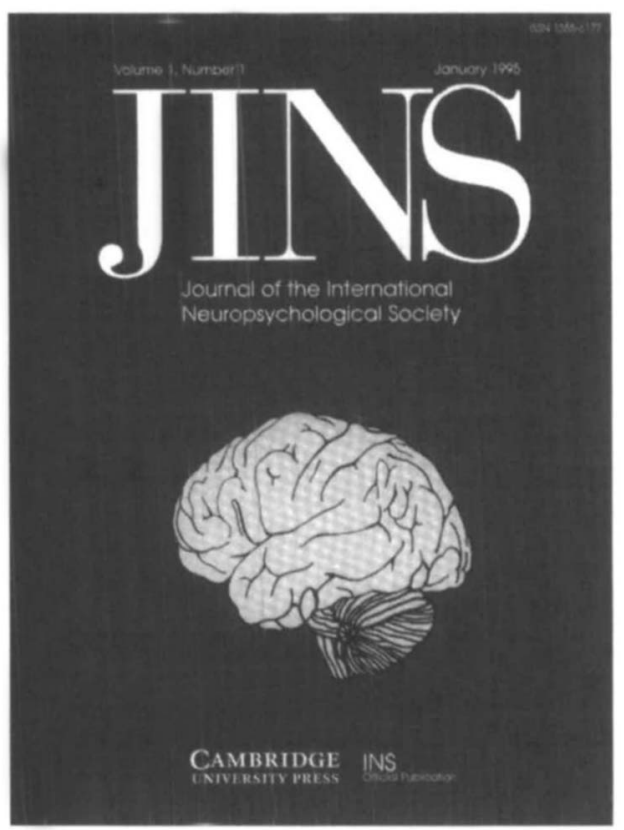

Bimonthly, ISSN 1355-6177 $\$ 160.00$ for Institutions $\$ 80.00$ for Individuals

Subscriptions: This essential journal may be ordered from your subscription agent or directly from Cambridge University Press, 40 West 20th Street, New York, NY 10011-4211. Tel: (800) 872-7423, exr. 154. Fax: (914) 937-4712. E-mail: journals_marketing@cup.org

For customers outside the US, Canada and Mexico, orders and inquiries must be addressed to Cambridge University Press, Journals Marketing Dept., The Edinburgh Building, Cambridge CB2 2RU, UK. Fax: 44(0) 1223 325959. E-mail: journals_marketing@cup.cam.ac.uk

Free sample copy available on request. 


\section{Behavioral and Brain Sciences}

\section{Instructions for Authors and Commentators}

Behavioral and Brain Sciences (BBS) is a unique scientific communication medium, providing the service of Open Peer Commentary for reports of significant current work in psychology, neuroscience, behavioral biology or cognitive science. If a manuscript is judged by BBS referees and editors to be appropriate for Commentary (see Criteria below), it is then circulated to a large number of commentators selected (with the aid of systematic bibliographic searches) from the BBS Associateship " and the worldwide biobehavioral science community, including individuals recommended by the author.

Once the Commentary stage of the process has begun, the author can no longer alter the article, but can respond formally to all commentaries accepted for publication. The target article, commentaries, and authors' response then co-appear in BBS. Continuing Commentary and replies can appear in later issues.

Criteria for acceptance To be eligible for publication, a paper should not only meet the standards of a journal such as Psychological Review or the International Review of Neurobiology in terms of conceptual rigor, empirical grounding, and clarity of style, but it should also offer a clear rationale for soliciting Commentary. That rationale should be provided in the author's covering letter, together with a list of suggested commentators.

A paper for BBS can be (i) the report and discussion of empirical research that the author judges to have broader scope and implications than might be more appropriately reported in a specialty journal; (ii) an unusually significant theoretical article that formally models or systematizes a body of research; or (iii) a novel interpretation, synthesis, or critique of existing experimental or theoretical work. Occasionally, articles dealing with social or philosophical aspects of the behavioral and brain sciences will be considered.

The service of Open Peer Commentary will be primarily devoted to original unpublished manuscripts. However, a recently published book whose contents meet the standards outlined above may also be eligible for Commentary. In such a BBS Multiple Book Review, a comprehensive, article-length precis by the author is published together with the commentaries and the author's response. In special cases, Commentary will also be extended to a position paper or an already published article dealing with particularly influential or controversial research. Submission of an article implies that it has not been published or is not being considered for publication elsewhere. Multiple book reviews and previously published articles appear by invitation only. The Assoclateship and professional readership of BBS are encouraged to nominate current topics and authors for Commentary.

In all the categories described, the decisive consideration for eligibility will be the desirability of Commentary for the submitted material. Controversiality simpliciter is not a sufficient criterion for soliciting Commentary: a paper may be controversial simply because it is wrong or weak. Nor is the mere presence of interdisciplinary aspects sufficient: general cybernetic and "organismic" disquisitions are not appropriate for BBS. Some appropriate rationales for seeking Open Peer Commentary would be that: (1) the material bears in a significant way on some current controversial issues in behavioral and brain sciences; (2) its findings substantively contradict some wellestablished aspects of current research and theory; (3) it criticizes the findings, practices, or principles of an accepted or influential line of work; (4) it unifies a substantial amount of disparate research; (5) it has important cross-disciplinary ramifications; (6) it introduces an innovative methodology or formalism for consideration by proponents of the established forms; (7) it meaningfully integrates a body of brain and behavioral data; (8) it places a hitherto dissociated area of research into an evolutionary or ecological perspective; etc. In order to assure communication with potential commentators (and readers) from other BBS specialty areas, all technical terminology must be clearly defined or simplified, and specialized concepts must be fully described.

Note to commentators The purpose of the Open Peer Commentary service is to provide a concentrated constructive interaction between author and commentators on a topic judged to be of broad significance to the biobehavioral science community. Commentators should provide substantive criticism, interpretation, and elaboration as well as any pertinent complementary or supplementary material, such as illustrations; all original data will be refereed in order to assure the archival validity of BBS commentaries. Commentaries and articles should be free of hyperbole and remarks ad hominem.

Style and format for articles and commentaries Target articles must not exceed 14,000 words (and should ordinarily be considerably shorter); commentaries should not exceed 1,000 words, including references. Spelling, capitalization, and punctuation should be consistent within each article and commentary and should follow the style recommended in the latest edition of A Manual of Style, The University of Chicago Press. It may be helpful to examine a recent issue of BBS.

All submissions must include an indexable title, followed by the authors' names in the form preferred for publication, full institutional addresses, and electronic mail addresses. Target article authors must also provide numbered subheads to facilitate cross-reference by commentators. Two abstracts, one of 100 and one of 250 words, should be submitted with every target article. The shorter abstract will appear one issue in advance of the article; the longer one will be circulated to potential commentators and will appear with the printed article. A list of 5-10 keywords should precede all target article texts. Notes, acknowledgments, appendices, and references should be grouped at the end of the target article or commentary.

Illustrations: Tables and figures (i.e., photographs, graphs, charts, or other artwork) should be numbered consecutively. Every table should have a title; every figure, a caption. At least one reference in the text must indicate the appropriate locations. (For sizes, see below.)

References: Bibliographic citations in the text must include the author's last name and the date of publication and may include page references. Complete bibliographic information for each citation should be included in the list of references. Examples of correct style are: Brown (1973); (Brown 1973); (Brown 1973; 1978); (Brown 1973; Jones 1976); (Brown \& Jones 1978); (Brown et al. 1979). References should be typed on a separate sheet in alphabetical order in the style of the following examples. Do not abbrevlate journal titles.

Kupfermann, I. \& Weiss, K. (1978) The command neuron concept. Behavioral and Brain Sciences 1:3-39.

Dunn, J. (1976) How far do early differences in mother-child relations affect later developments? In: Growing points in ethology, ed. P. P. G.

Bateson \& R. A. Hinde. Cambridge University Press

Bateson, P. P. G. \& Hinde, R. A., eds. (1976) Growing points in ethology. Cambridge University Press.

Preparation of the manuscript The original, double-spaced target article plus eight single-spaced, double-sided copies must be submitted. The entire manuscript, including notes and references, must be typed double-spaced ( $1 / 4$-inch space between lines) on $8 \frac{1}{2}$ by 11 inch paper, with margins set to 70 characters per line (not "justified") and 25 lines per page, and should not exceed 50 pages. Pages should be numbered consecutively. Commentators should send their original plus two copies. It will be necessary to return manuscripts for retyping if they do not conform to this standard.

Each table and figure should be submitted on a separate page, nol interspersed with the text. Tables should be typed to conform to BBS style. Figures should be ready for photographic reproduction; they cannot be redrawn by the printer. Charts, graphs, or other artwork should be done in black ink on white paper and should be drawn to occupy a standard area of $8^{1 / 2}$ by 11 or $81 / 2$ by $5 \frac{1}{2}$ inches before reduction. Photographs should be glossy black-and-white prints; 8 by 10 inch enlargements are preferred. All labels and details on figures should be clearly printed and large enough to remain legible even after a reduction to half size. It is recommended that labels be done in transfer type of a sans-serif face such as Helvetica.

All submissions should include a diskette in Word ${ }^{\text {TM }}$ or WordPerfect ${ }^{\text {Tw }}$ for Macintosh or IBM-compatible computers and containing the full manuscript. Target articles should be sent to: Stevan Harnad, Editor, Behavioral and Brain Sciences, Department of Psychology, University of Southampton, Highfield, Southampton, SO171BJ, United Kingdom. Phone: +44 (0)1703-594-583. Electronic mall: bbs@ecs.soton.ac.uk. Commentaries should be sent to: Behavioral and Brain Sciences, Cambridge University Press, Journals Department, 40 West 20th Street, New York, NY 10011-4211. Phone: 212 924-3900 (ext. 369). Electronic mail: bbs@cup.org. In case of doubt as to appropriateness for BBS commentary, authors should write to the editor before submitting eight copies.

Editing The publishers reserve the right to edit and proof all articles and commentaries accepted for publication. Authors of articles will be given the opportunity to review the copyedited manuscript and page proofs. Commentators will be asked to review copyediting only when changes have been substantial; commentators will not see proofs. Both authors and commentators should notify the editorial office of all corrections within 48 hours or approval will be assumed.

Authors of target articles receive 50 offprints of the entire treatment, and can purchase additional copies. Commentators will also be given an opportunity to purchase offprints of the entire treatment.

"Individuals interested in serving as BBS Associates are asked to write to the editor. 


\section{To appear in Volume 19, Number 1 (1996)}

Offprints of the following forthcoming BBS treatments can be purchased for educational purposes if they are ordered well in advance. For ordering information, please write to Journals Department, Cambridge University Press, 40 West 20th Street, New York, NY 10011.4211.

\section{The base rate fallacy reconsidered: Descriptive, normative and methodogical challenges}

\section{Jonathan J. Koehler, University of Texas at Austin}

We have been oversold on the base rate fallacy in probabilistic judgement from an empirical, normative, and nethodogical standpoint. First, contrary to the conventional wisdom, a thorough examination of the literature reveals that base rates are almost always used and that their degree of use depends ori task structure and internal task representation. Second, few tasks map unambiguously into the simple, narrow framework that is held up as the standard of good decision making. Third, the current approach is criticized for its failure to consider how the ambiguous, unreliable and unstable base rates of the real world should be used in the informationally rich and criterion-complex natural environment. A more ecologically valid research program is called for. With Commentary from NH Anderson; U Cohen; RM Dawes; G. Gigerenzer; G Keren \& U Thijs; GD Kleiter; J Krueger \& WS Hunter; HF. Kyburg; I Levi; H Margolis; BA Spellman; PD Windschitl \& GL Wells; and others.

\section{What are "normal movements" in atypical populations?}

\section{Mark L. Latash, Pennsylvania State University, and J. Greg Anson, University of Otago}

Patterns of voluntary movements reflect priorities (coordinative rules) of the central nervous system that help it overcome the problem of redundancy. In certain atypical conditions, that may include cognitive, central neurological, and peripheral disorders, the central nervous system may reconsider its priorities. In such conditions, changed motor patterns should be viewed not as pathological but rather as adaptive to a primary disorder. In fact, perhaps they may even be viewed as optimal for a given state of the system of movement production. Thus, therapeutic approaches should not be directed towards restoring the motor patterns to as close to "normal" as possible, but rather towards resolving the original underlying problem

With Commentary from A Berardelli et al.; E Biryukova \& AA Frolov; JM Gurd; RL Glatzky; RSW Masrers \& RCJ Polman; KM Newell \& S Newell; JP Scholz; E Thelen; PJ Treffner \& JAS Kelso; REA van Emmeik \& RC Wagenaar; AM Wing; and others.

\section{Intentional relations and social understanding John Barresi and Chris Moore, Dalhousie University}

We present a theory of social understanding based on a view of intentional relations as a species of causal relation. A system for the uniform representation of intentional relations of self and other uses a generalized capacity to share intentional relations and an intentional schema to generate and integrate first person information of an intentional relation of self with third person information of a comparable intentional relation of another. A four level framework of representations that do and do not require the intentional scherna can explain the phylogeny and ontogeny of social understanding and perhaps autism.

With Commentary from S Baron-Cohen; A Ben Ze' ev \& K Oatley; G Csibra \& G Gergely; G Gallup; JC Gomez; RM Gordon; C Heyes; P Hobson; RW Mitchell; K Nelson; A Oosterwegel, D \& A Premack; C Slater; and others.

Among the articles to appear in forthcoming issues of BBS:

A Koriat \& M Goldsmith, "Memory metaphors and the every day laboratory controversy: The correspondence versus storehouse conceptions of memory"

JJ Wright \& DTJ Lilley, "Dynamics of the brain at global and microscopic scales: Neural networks and the EEG"

D Geary, "Sexual selection and sex differences in mathematical abilities"

"Controversies in Neurnscience IV" (Motor learning and synaptic plasticity in the cerebellum): "Controversies in Neuroscience V" (Persistent pain); SD Epstein, S Flynn \& G Martohardjono, "Second language acquisition: Theoretical and experimental issues in contemporary research"; R-A Müller, "Innateness, autonomy, universality?: Neurobiological approaches to language";

GH Heyman, "Resolving the contradictions of addiction"; V Braitenberg, D Heck \& F Sultan, "The detection and generation of sequences as a key to cerbellar function: Experiments and theory"; AM Glenberg, "What memory is for 